\title{
Tubeless PCNL in Macrotract for Multiple and Staghorn Calculus with More Than One Tract- A Single Centre Experience and Literature Review
}

\author{
Ahsan Ahmad ${ }^{1}$, Kumar Gaurav Mishra², Kamlesh Gunjan³ ${ }^{3}$ Gaurav \\ ${ }^{1}$ Department of Urology, IGIMS, Patna, Bihar, India. ${ }^{2}$ Department of Urology, Mahavir \\ Cancer Sansthan And Research Centre, Phulwari Sharif, Patna, Bihar India. ${ }^{3}$ Department of \\ Urology, AIIMS, Patna, Bihar, India. ${ }^{4}$ Department of Urology, IGIMS, Patna, Bihar, India.
}

\section{ABSTRACT}

\section{BACKGROUND}

Percutaneous nephrolithotomy (PCNL) has gradually become a preferred method of treatment modality for kidney stones in adults as well as in paediatric patients. The primary objective of this study was to evaluate the outcomes and complications in patients having multiple and staghorn calculi and of different sizes, who underwent tubeless PCNL at a single, tertiary care hospital.

\section{METHODS}

A retrospective study was conducted at IGIMS, Patna from January 2017 to February 2018. Patients who underwent conventional PCNL with one or two access for single, multiple or staghorn calculus without nephrostomy tube were included in the study. Patients having solitary kidney with stones are excluded from this study. The primary outcomes of the study were haemoglobin, pain score, and duration of hospital stay.

\section{RESULTS}

A total of 96 patients underwent conventional PCNL with a mean age of 34 years and male:female ratio of 1.3:1. Majority of the patients had a single stone $(n=54)$ followed by 28 patients with multiple stones. Medical comorbidities including hypertension, diabetes mellitus and chronic obstructive pulmonary disease were observed in patients of single $(n=8)$, multiple $(n=3)$ and staghorn $(n=2)$ groups, respectively. Postoperative complications such as haematuria and pleural effusion were developed by the patients. Seventy-six patients were treated with single-tract and 20 by double tract PCNL.

\section{CONCLUSIONS}

PCNL is safe and efficient with limited post-operative complications. The number of residual stones were nil in single stone group while in multiple and staghorn groups insignificant number of renal stones was seen.

\section{KEY WORDS}

Comorbidities, Haematuria, Nephrostomy, Kidney Stones, Pleural Effusion
Corresponding Author: Kumar Gaurav Mishra, Department of Urology, Mahavir Cancer Sansthan And Research Centre, Phulwari Sharif, Patna, Bihar. India.

E-mail: gauravmishra.pmch@gmail.com DOI: $10.14260 /$ jemds/2020/281

Financial or Other Competing Interests: None.

How to Cite This Article:

Ahmad A, Mishra KG, Gunjan K, et al. Tubeless PCNL in macrotract for multiple and staghorn calculus with more than one tract- a single centre experience and literature review. J. Evolution Med. Dent. Sci. 2020;9(15):1295-1299, DOI: $10.14260 /$ jemds/2020/281

Submission 07-02-2020,

Peer Review 21-03-2020,

Acceptance 27-03-2020,

Published 13-04-2020.

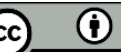




\section{BACKGROUND}

Renal calculi or kidney stones have been showing an increasing trend in their relapse rate and prevalence in all ages, genders and races. Renal calculi formation is multifactorial and patients with renal diseases,[1] cardiovascular diseases, diabetes, and hypertension have greater risk of developing renal calculi.[2,3,4] The risk of renal stone varies from $1-5 \%$ in Asia and about $12 \%$ Indian population shows its presence.[5,6]

Availability of limited drugs for the treatment of renal calculi has led to the advances of surgical technology with nominal modality invasive treatment such as Percutaneous nephrolithotomy (PCNL).[7] PCNL has advanced gradually over the years and according to the European Association of Urology (EAU) guidelines (2017), is now a first-line of treatment for kidney and upper ureteral calculi.[8] Untreated renal calculi especially staghorn type causes further complications increasing the risk of morbidity and mortality thus, PCNL or a combination of multimodality treatments are used. PCNL was associated with morbidities such as bleeding, pyrexia, incomplete stone removal, pleural injury, and adjacent organ injury.[9] Refinements in the technique and better lithotripsy technologies have led to a reduction in these morbidities. In the standard PCNL procedure, after stone removal, a nephrostomy is placed. In the later years, tubeless PCNL was introduced with the insertion of a double J ureteric stent following PCNL. However, the presence of double-J stent in tubeless PCNL is often associated with stentrelated problems such as frequency, urgency, nocturia, pain, and hematuria.[10] Recently, a more advanced technique called totally tubeless PCNL was introduced in which a nephrostomy catheter, a double J stent, or a ureteral catheter are not inserted after surgery.[11]

Studies reveal significantly lowered hospital stay, pain profiles, and use of analgesics in patients undergoing the tubeless PCNL technique. Percutaneous method is beneficial in terms of tolerance, recovery and expenses.[12,13] The residual stone rate after PCNL (13.3-16.2\%) is comparable to open surgery (0-24\%).[14-16] Studies have been conducted to determine the safety and efficacy of tubeless, totally tubeless and conventional PCNL.[17]

The primary objective of this study was to evaluate the outcomes and complications in patients having multiple and staghorn calculi and of different sizes, who underwent tubeless PCNL at a single, tertiary care hospital.

\section{METHODS}

This was a retrospective study conducted at IGIMS, Patna. The study protocol was approved by Institutional Review Board and Ethics Committee. Written informed consent was obtained from all the patients before undergoing percutaneous nephrolithotomy (PCNL).

The patients who underwent conventional PCNL with one or two access for single, multiple or staghorn calculus without nephrostomy tube from January 2017 to February 2018 were included in the study. All preoperative investigations like complete blood count (CBC), kidney function tests (KFT), random blood sugar (RBS), intravenous urogram (IVU) and computed tomography (CT) urography were completed. Postoperatively $\mathrm{CBC}, \mathrm{KFT}$, and $\mathrm{X}$ ray KUB were done in all the patients. The medical records of all the included patients were reviewed and clinical data was recorded.

The procedure was performed under aseptic condition. A ureteral catheter was introduced into the renal pelvis. The patient was inclined to access percutaneously into the corresponding pelvicalyceal system by image intensification using an 18-gauge needle. The tract was dilated using a single-step $30 \mathrm{~F}$ dilator. Renal stones were fragmented using ballistic lithotripsy. Post-operative stone clearance was checked with X-ray.

The patients having solitary kidney with stones are excluded from this study. The primary outcomes of the study were haemoglobin, pain score, duration of hospital stay.

Data analysis included stone size and number, number of access tracts, medical comorbidities, post-operative complications and stone-free status.

\section{RESULTS}

A total of 96 patients who underwent conventional PCNL with a mean age of 34 years were included for analysis. Of 96 patients, the male: female ratio was 1.3:1. The patients were examined clinically and investigated post operatively on POD (post-operative day)

In this study one patient became serious and was shifted to surgical intensive care unit for septicaemic shock but patient revived and then discharged from hospital. The demographic characteristics of the study are listed in Table. The post-operative complications and the main outcomes of the study are listed in Table 1. Majority of the patients had single stone $(n=54)$ followed by 28 patients with multiple stones and 14 patients. Medical comorbidities including hypertension, diabetes mellitus and chronic obstructive pulmonary disease were observed in eight, three and two patients of single, multiple and staghorn groups respectively. Postoperative complications such as haematuria and pleural effusion were developed by the patients. Among the total patients six patients developed haematuria and only one patient in multiple stone group developed pleural effusion.

\begin{tabular}{|c|c|c|c|c|c|c|c|c|}
\hline \multirow{2}{*}{ 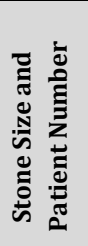 } & \multirow{2}{*}{ 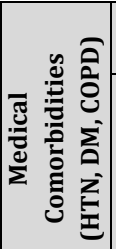 } & \multicolumn{2}{|c|}{ Side } & \multicolumn{2}{|c|}{$\begin{array}{c}\text { Number of } \\
\text { Tracts }\end{array}$} & \multicolumn{2}{|c|}{$\begin{array}{l}\text { Postoperative } \\
\text { Complications }\end{array}$} & \multirow{2}{*}{ 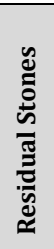 } \\
\hline & & ङ్త & $\sum_{\frac{1}{20}}^{=10}$ & $\stackrel{0}{\rightleftarrows}$ & 产 & 芛 & 苋 & \\
\hline $\begin{array}{c}\text { Single } \\
(\mathrm{n}=54)\end{array}$ & $\begin{array}{c}8 \\
(14.8) \\
\end{array}$ & $\begin{array}{c}30 \\
(55.6) \\
\end{array}$ & $\begin{array}{c}24 \\
(44.4) \\
\end{array}$ & $\begin{array}{c}50 \\
(92.6) \\
\end{array}$ & $\begin{array}{c}4 \\
(7.4) \\
\end{array}$ & $\begin{array}{c}2 \\
(3.7) \\
\end{array}$ & - & Nil \\
\hline $\begin{array}{c}\text { Multiple } \\
(\mathrm{n}=28)\end{array}$ & $\begin{array}{c}3 \\
(10.7) \\
\end{array}$ & $\begin{array}{c}16 \\
(57.1) \\
\end{array}$ & $\begin{array}{c}12 \\
(42.9) \\
\end{array}$ & $\begin{array}{c}20 \\
(71.4) \\
\end{array}$ & $\begin{array}{c}8 \\
(28.6) \\
\end{array}$ & $\begin{array}{c}3 \\
(10.7) \\
\end{array}$ & $1(3.5)$ & $\begin{array}{c}2 \\
(7.1) \\
\end{array}$ \\
\hline \begin{tabular}{|c|} 
Staghorn \\
$(\mathrm{n}=14)$
\end{tabular} & $\begin{array}{c}2 \\
(14.3) \\
\end{array}$ & $\begin{array}{c}4 \\
(28.6) \\
\end{array}$ & $\begin{array}{c}10 \\
(71.4) \\
\end{array}$ & $\begin{array}{c}6 \\
(42.9) \\
\end{array}$ & $\begin{array}{c}8 \\
(57.1) \\
\end{array}$ & $\begin{array}{c}1 \\
(7.1)\end{array}$ & - & $\begin{array}{c}1 \\
(7.1) \\
\end{array}$ \\
\hline \multicolumn{9}{|c|}{$\begin{array}{l}\text { Table 1. Characteristics of Kidney Stones, Medical } \\
\text { Comorbidities and Post-Operative Complications }\end{array}$} \\
\hline
\end{tabular}




\begin{tabular}{|c|c|c|c|c|c|c|}
\hline 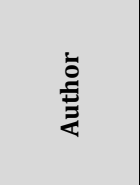 & むี & 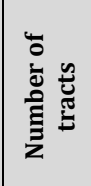 & | & 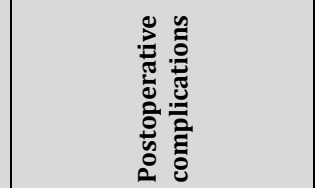 & 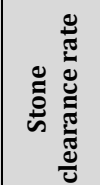 & ¿ֶّ \\
\hline Wu et al & 2019 & \begin{tabular}{|c|} 
Single, \\
multiple
\end{tabular} & - & $\begin{array}{c}\text { Fever, hematuria with blood clot, } \\
\text { hypokalaemia, urine leakage }\end{array}$ & $89.7,100$ & {$[28]$} \\
\hline $\begin{array}{l}\text { Zhao } \\
\text { et al }\end{array}$ & 2019 & $\begin{array}{l}\text { Single, } \\
\text { multiple }\end{array}$ & $\begin{array}{l}\text { HTN, } \\
\text { DM }\end{array}$ & $\begin{array}{c}\text { Fever, obvious hematuria with } \\
\text { blood clot, hypokalaemia, urine } \\
\text { leakage }\end{array}$ & $89.7,100$ & [29] \\
\hline Raharja et al & 2019 & - & - & Urine leakage & & [30] \\
\hline $\begin{array}{l}\text { Ichaoui } \\
\text { et al }\end{array}$ & 2019 & - & $\begin{array}{l}\text { HTN, } \\
\text { DM, } \\
\text { CAD, } \\
\text { Renal } \\
\text { failure }\end{array}$ & $\begin{array}{l}\text { Pyelonephritis, urinary fistula, } \\
\text { urinoma, fever, pleural breach, } \\
\text { digestive breach, arteriovenous } \\
\text { fistula, blood transfusion }\end{array}$ & 72.5 & {$[31]$} \\
\hline $\begin{array}{l}\text { Gupta } \\
\text { et al }\end{array}$ & 2019 & Single & - & $\begin{array}{c}\text { Fever, perinephric collection, } \\
\text { blood transfusion }\end{array}$ & 92.4 & {$[32]$} \\
\hline Kim et al & 2019 & - & - & Hematoma or urinoma & 91.1 & [33] \\
\hline Bryniarski et al & 2019 & - & $\begin{array}{c}\text { HTN, } \\
\text { DM }\end{array}$ & Fever, leucocyturia & - & [34] \\
\hline Sourial et al & 2019 & - & - & $\begin{array}{l}\text { Thoracic complications } \\
\text { pneumothorax, and pleural } \\
\text { effusion, bleeding requiring } \\
\text { transfusion, fever, urinary } \\
\text { retention and syncope }\end{array}$ & 68.5 & {$[35]$} \\
\hline Iqbal et al & 2018 & - & - & Urinary leakage, fever, UTI & 96 & {$[36]$} \\
\hline $\begin{array}{c}\text { Keshavamurth } \\
\text { y et al }\end{array}$ & 2018 & - & - & $\begin{array}{l}\text { Fever, paralytic ileus, urinary } \\
\text { leakage }\end{array}$ & - & [37] \\
\hline $\begin{array}{l}\text { Sofer } \\
\text { et al }\end{array}$ & 2017 & - & - & Blood transfusion, $\mathrm{Hb}$ drop & 89 & {$[38]$} \\
\hline $\begin{array}{l}\text { Bhat } \\
\text { etal }\end{array}$ & 2017 & - & - & \begin{tabular}{|c|}
$\begin{array}{c}\text { Blood transfusion, fever, urinary } \\
\text { leakage, haemorrhage }\end{array}$ \\
\end{tabular} & - & {$[17]$} \\
\hline $\begin{array}{l}\text { Ming } \\
\text { et al }\end{array}$ & 2017 & - & - & $\begin{array}{c}\text { Blood transfusion, fever, pleural } \\
\text { effusion, HB drop }\end{array}$ & 96.7 & {$[39]$} \\
\hline $\begin{array}{c}\text { Terao } \\
\text { et al }\end{array}$ & 2015 & $\begin{array}{c}\text { Single, } \\
\text { multiple }\end{array}$ & - & Fever, blood transfusion & 90.2 & [40] \\
\hline Jou et al & 2015 & - & - & Fever, UTI & 75.7 & {$[41]$} \\
\hline $\begin{array}{c}\text { Zhang } \\
\text { et al }\end{array}$ & 2015 & - & - & Fever, blood transfusion, & 96.3 & [42] \\
\hline $\begin{array}{l}\text { Zhao } \\
\text { et al }\end{array}$ & 2015 & - & - & $\begin{array}{l}\text { Haemorrhage with bleeding, } \\
\text { pleural injury, thoracentesis }\end{array}$ & 98.3 & [43] \\
\hline $\begin{array}{l}\text { Kara-koyunlu } \\
\text { et al }\end{array}$ & 2014 & - & - & $\begin{array}{c}\text { Fever, blood transfusion, urinary } \\
\text { leakage, perirenal hematoma, } \\
\text { neighbouring organ injury, toxic } \\
\text { hepatitis }\end{array}$ & 97.5 & {$[44]$} \\
\hline Joo et al & 2014 & - & - & Bleeding, fever & 76.5 & {$[45]$} \\
\hline $\begin{array}{c}\text { Gonen } \\
\text { et al }\end{array}$ & 2014 & - & - & Bleeding & 95 & [46] \\
\hline $\begin{array}{l}\text { Rifaioglu } \\
\text { et al }\end{array}$ & & $\begin{array}{c}\text { Single, } \\
\text { multiple }\end{array}$ & - & Bleeding & 93.5 & [47] \\
\hline $\begin{array}{l}\text { Agrawal } \\
\text { etal }\end{array}$ & & - & - & \begin{tabular}{|c|} 
Fever, blood transfusion, urinary \\
leakage,
\end{tabular} & - & {$[27]$} \\
\hline $\begin{array}{l}\text { Pillai } \\
\text { et al }\end{array}$ & 2014 & Single & - & $\begin{array}{c}\text { Blood transfusion, pneumonia, } \\
\text { hydrothorax, urosepsis }\end{array}$ & 95 & [48] \\
\hline Lee et al & 2013 & - & - & $\begin{array}{l}\text { Bleeding, angioembolization, } \\
\text { fever, wound infection }\end{array}$ & 78 & [49] \\
\hline $\begin{array}{l}\text { Ziaee } \\
\text { et al }\end{array}$ & 2013 & - & - & Bleeding, fever, urinary leakage & 98 & {$[50]$} \\
\hline $\begin{array}{c}\text { Xiong } \\
\text { et al }\end{array}$ & 2013 & - & - & HB decrease, fever & 99.1 & [51] \\
\hline $\begin{array}{l}\text { Garofalo } \\
\text { et al }\end{array}$ & 2013 & - & - & Fever, bleeding & - & [52] \\
\hline $\begin{array}{l}\text { Gonulalan } \\
\text { etal }\end{array}$ & 2013 & - & - & Fever, bleeding & 90 & [53] \\
\hline $\begin{array}{l}\text { Nalbant } \\
\text { et al }\end{array}$ & 2012 & - & $\begin{array}{c}\text { HTN, } \\
\text { DM, } \\
\text { chronic } \\
\text { respira } \\
\text { tory } \\
\text { disease }\end{array}$ & Haemorrhage & 91.6 & {$[54]$} \\
\hline $\begin{array}{c}\text { Samad } \\
\text { et al }\end{array}$ & 2012 & - & - & Pain, urine leakage & 93.3 & {$[55]$} \\
\hline $\begin{array}{l}\text { Gudeman } \\
\text { et al }\end{array}$ & 2012 & - & - & $\begin{array}{c}\text { Bleeding, pseudoaneurysm, } \\
\text { urine leakage }\end{array}$ & 90 & {$[56]$} \\
\hline $\begin{array}{l}\text { Etemadian } \\
\text { et al }\end{array}$ & 2012 & - & - & Fever & 83.3 & {$[57]$} \\
\hline $\begin{array}{l}\text { Zilberman } \\
\text { et al }\end{array}$ & 2010 & - & - & \begin{tabular}{|} 
Pulmonary embolus, \\
hydrothorax, pseudoaneurysm \\
or arteriovenous fistula
\end{tabular} & 89 & [58] \\
\hline Sofer et al & 2010 & - & - & $\begin{array}{l}\text { Bleeding, hydrothorax, } \\
\text { extravasation }\end{array}$ & 91 & [59] \\
\hline Lojanapiwat & 2010 & - & - & $\begin{array}{c}\text { Haemorrhage, pleural } \\
\text { complication, Intercostal } \\
\text { drainage }\end{array}$ & 86.7 & {$[60]$} \\
\hline Jun-Ou et al & 2010 & - & - & Pleural complication & 90.7 & {$[$ [61] } \\
\hline \multicolumn{7}{|c|}{$\begin{array}{l}\text { Table 2. Studies of Tubeless PCNL } \\
\text { Reported in Literature of Last } 10 \text { Years }\end{array}$} \\
\hline
\end{tabular}
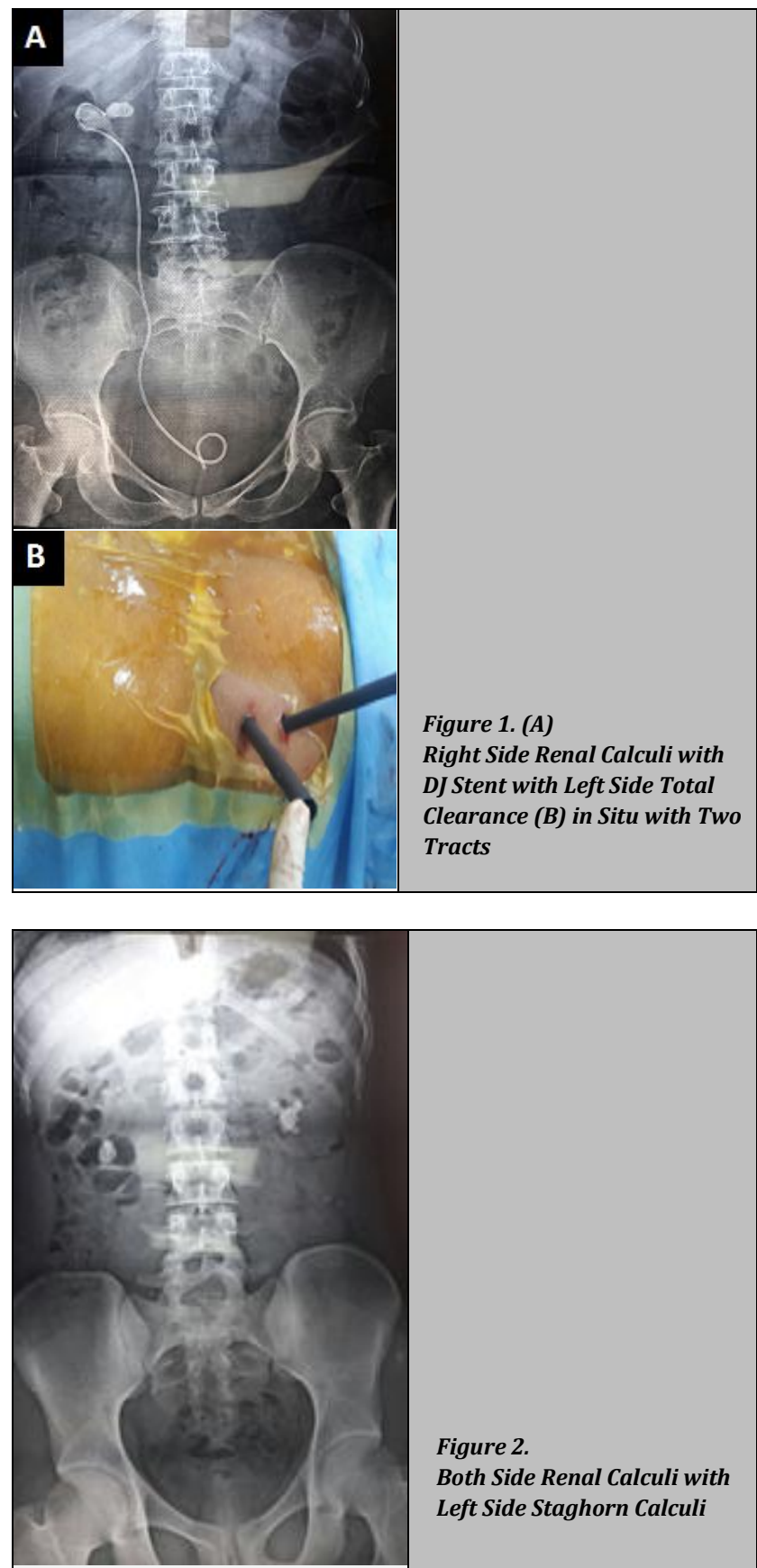

\section{DISCUSSION}

PCNL is although an ideal procedure for management of renal calculi whether single, multiple or staghorn, is a very challenging endourologic measure of treatment. Medical literature has reported excellent stones free rates with this procedure. In this study the outcomes of the tubeless PCNL for a series of patients with single, multiple or staghorn calculi of varying sizes and multiple tracts was evaluated.

The response to this to this procedure was very well with nil residual stones in patients with single calculi and 7\% in multiple and staghorn renal calculi. Medical comorbidities like hypertension, diabetes melitis and COPD in 13 among 96 patients. Similar comorbidities were reported by Soucy et al. along with cardiac, neurologic and in few renal failures.

Placing more than 2-3 tracts during PCNL increases the risk of complications, hence urologists hesitant to use multi 
tracts. Studies have been carried out to support multi-tract PCNL for large staghorn calculi. Aron et al. reported less morbidity with usage of multiple tracts with a clearance rate of $84 \%$ that improved to $94 \%$ with adjunctive shockwave lithotripsy (SWL). It was observed that $81 \%$ patients with double tracts did not require transfusion. ${ }^{[18]}$ In the present study single and double tracts were used and majority patients were fitted with single tract in all the groups including single stone, $92.6 \%$, multiple, stones, $71.4 \%$ and staghorn $42.9 \%$. Double tract was placed in $7.4 \%$ patients of single stone group and $28.6 \%$ and $57.1 \%$ of patients in multiple and staghorn. In another study by Soucy et al. wherein 1338 patients with staghorn calculi underwent PCNL were evaluated for outcomes and major complications of PCNL. The study reported $16 \%$ of the cases requiring multiple access tracts with 78 stone free rates during hospital discharge. In an Indian study by Gupta et al. observed postoperative complications like fever (7.5\%) perinephric collection (5.6\%) and blood transfusion (3.7\%).

The efficacy of intercostal nerve block and nephrostomy tract infiltration (NTI) with ropivacaine in patients undergoing tubeless PCNL was found to be safe.[19]

A meta-analysis by Zhong et al. showed that totally tubeless PCNL is an ideal method of treatment that significantly condenses the hospital stay, analgesic requirement, and the time to return to normal activity without increased complications. Because this series consists of our early experiences with tubeless PCNL, we routinely placed a ureteral stent during tubeless PCNL due to safety concerns.[20] A meta-analysis conducted by Wang et al. indicated that the haemostatic agents in tubeless PCNL are expected to be expensive rather than unsafe and not mandatory to be used whereas another study by $\mathrm{Yu}$ et al. revealed that haemostatic agents exhibited a short hospital stay.[21,22]

PCNL procedure requires patients routinely to be hospitalized postoperatively. To lessen the constant rising healthcare costs, efforts are made to move PCNL to outpatient surgery.[23-25] Outpatient surgery would be beneficial in providing a more rapid patient recovery, and decreased postoperative nosocomial infections, hence less morbidity Our initial experience with outpatient PCNL has been favourable and warrants further investigation in a larger patient population.[26] Agrawal et al. reported a study wherein advantages of tubeless PCNL with tethered DJ stent was evaluated that was found to overcome its main drawback i.e. the need for cystoscopy for stent removal.[27] Various studies of tubeless PCNL are conducted in regards to its safety, efficacy, cost, hospital stay and stone clearance in comparison to standard PCNL. Table 2 depicts the clinical studies of tubeless PCNL conducted in patients having renal calculi of different types, and with single or multiple tracts.

The main limitation of this study was the retrospective nature of our study. The other factor was the limited selection of patients in this study. The tubeless method has been reported in challenging cases such as staghorn stones, horseshoe or ectopic kidneys. Promising outcomes have been demonstrated in elderly patients and circumstances requiring a supracostal approach. Multi-centre randomised controlled trials are desired to fully establish the success of the tubeless method.[28]

\section{CONCLUSIONS}

PCNL using multiple tracts is safe and effective with limited post-operative complications and should be the first option for massive renal staghorn calculi. The number of residual stones with tubeless PCNL were nil in single stone group while in multiple and staghorn groups, minimal number of renal stones was seen.

\section{REFERENCES}

[1] Mikawlrawng K, Kumar S, Vandana R. Current scenario of urolithiasis and the use of medicinal plants as antiurolithiatic agents in Manipur (North East India): a review. International Journal of Herbal Medicine 2014;2(1):1-12.

[2] Rule AD, Roger VL, Melton 3rd LJ, et al. Kidney stones associate with increased risk for myocardial infarction. J Am Soc Nephrol 2010;21(10):1641-4.

[3] Worcester EM, Coe FL. Nephrolithiasis. Primary Care 2008;35(2):369-91.

[4] Taylor EN, Stampfer MJ, Curhan GC. Obesity, weight gain and the risk of kidney stones. JAMA 2005;293(4):455-62.

[5] Romero V, Akpinar H, Assimos DG. Kidney stones: a global picture of prevalence, incidence and associated risk factors. Rev Urol 2010;12(2-3):e86-96.

[6] Guha M, Banerjee H, Mitra P, et al. The demographic diversity of food intake and prevalence of kidney stone diseases in the Indian continent. Foods 2019;8(1):37.

[7] Fernström I, Johansson B. Percutaneous pyelolithotomy: a new extraction technique. Scand J Urol Nephrol 1976;10(3):257-9.

[8] Türk C, Petř́lk A, Sarica K, et al. EAU guidelines on diagnosis and conservative management of urolithiasis. Eur Urol 2016;69(3):468-74.

[9] De la Rosette J, Assimos D, Desai M, et al. The clinical research office of the endourological society percutaneous nephrolithotomy global study: indications, complications and outcomes in 5803 patients. J Endourol 2011;25(1):11-7.

[10] Saltzman B. Ureteral stents. Indications, variations and complications. Urol Clin North Am 1988;15(3):481-91.

[11] Moosanejad N, Firouzian A, Hashemi SA, et al. Comparison of totally tubeless percutaneous nephrolithotomy and standard percutaneous nephrolithotomy for kidney stones: a randomized, clinical trial. Braz J Med Biol Res 2016;49(4):e4878.

[12] Chang CH, Wang CJ, Huang SW. Totally tubeless percutaneous nephrolithotomy: a prospective randomized controlled study. Urol Res 2011;39(6):45965.

[13] Crook TJ, Lockyer CR, Keoghane SR, et al. Totally tubeless percutaneous nephrolithotomy. J Endourol 2008;22(2):267-71.

[14] Morey AF, Nitahara KS, McAninch JW. Modified anatrophic nephrolithotomy for management of staghorn calculi: is renal function preserved? J Urol 1999;162(3 Pt 1):670-3. 
[15] Koga S, Arakaki Y, Matsuoka M, et al. Staghorn calculi: long-term results of management. $\mathrm{Br} J$ Urol 1991;68(2):122-4.

[16] Snyder JA, Smith AD. Staghorn calculi: percutaneous extraction versus anatrophic nephrolithotomy. J Urol 1986;136(2):351-4.

[17] Bhat S, Lal J, Paul F. A randomized controlled study comparing the standard, tubeless and totally tubeless percutaneous nephrolithotomy procedures for renal stones from a tertiary care hospital. Indian J Urol 2017;33(4):310-14.

[18] Aron M, Yadav R, Goel R, et al. Multi-tract percutaneous nephrolithotomy for large complete staghorn calculi. Urol Int 2005;75(4):327-32.

[19] Choi SW, Cho SJ, Moon HW, et al. Effect of intercostal nerve block and nephrostomy tract infiltration with ropivacaine on postoperative pain control after tubeless percutaneous nephrolithotomy: a prospective, randomized and case-controlled trial. Urology 2018;114:49-55.

[20] Zhong Q, Zheng C, Mo J, et al. Total tubeless versus standard percutaneous nephrolithotomy: a metaanalysis. J Endourol 2013;27(4):420-6.

[21] Wang J, Zhang C, Tan G, et al. The use of adjunctive hemostatic agents in tubeless percutaneous nephrolithotomy: a meta-analysis. Urolithiasis 2014;42(6):509-17.

[22] Yu C, Xu Z, Long W, et al. Hemostatic agents used for nephrostomy tract closure after tubeless PCNL: a systematic review and meta-analysis. Urolithiasis 2014;42(5):445-53.

[23] Lehmann KJ, Beiko D. Outpatient tubeless percutaneous nephrolithotomy and concomitant cystolitholapaxy. Can Urol Assoc J 2014;8(3-4):E179-80.

[24] Bechis SK, Han DS, Abbott JE, et al. Outpatient percutaneous nephrolithotomy: The UC San Diego health experience. J Endourol 2018;32(5):394-401.

[25] Fahmy A, Rhashad H, Algebaly O, et al. Can percutaneous nephrolithotomy be performed as an outpatient procedure? Arab J Urol 2017;15(1):1-6.

[26] Beiko D, Lee L. Outpatient tubeless percutaneous nephrolithotomy: the initial case series. Can Urol Assoc J 2010;4(4):E86-90.

[27] Agrawal MS, Sharma M, Agarwal K. Tubeless percutaneous nephrolithotomy using antegrade tether: a randomized study. J Endourol 2014;28(6):644-8.

[28] Amer T, Ahmed K, Bultitude M, et al. Standard versus tubeless percutaneous nephrolithotomy: a systematic review. Urol Int 2012;88(4):373-82. 